\title{
Towards an African-American Genealogy of Market and Religion in Rap Music
}

\author{
Kevin Pyon \\ The University of North Carolina, Chapel Hill, NC, USA
}

\begin{abstract}
This essay provides a new reading of the intersections between religion and rap music in its genealogical consideration of how black laborers' orientations to the market-from the antebellum slave market to the contemporary music industry-have informed their consequent commodifications of race and religion. The essay (1) traces the informal economy and sacred world of the slaves to the twinned births of the modern black prosperity gospel and hip-hop culture and (2) connects the religio-economic modalities of postbellum peddling and celebrity preachers to contemporary black prosperity preachers and hip-hop moguls. Finally, this essay concludes that the commodified formulations of race and religion in rap music represent transformations of spiritual and market categories of "authenticity" and "freedom" which have structured and sometimes limited our understandings of distinct articulations of race, religion, and the market throughout African-American history.
\end{abstract}

\section{Articulations of Race, Religion, and the Market}

This essay situates hip-hop music within a lineage of black laborers who have both negotiated with and disrupted the market's commodification of them through various means: the medium of the market itself, their religious belief and practices, and-oftentimes-a paradoxical combination of both. ${ }^{1}$ It argues that the commodified formulations of race and religion in rap music signify the evolution of ideological categories of "authenticity" and "freedom" (amongst others), which have structured and sometimes limited our understandings of distinct articulations of race, religion, and the market throughout black history. ${ }^{2}$ This essay charts key epochs of black religio-economic history (from the informal economy and sacred world of the slaves to the concomitant births of the modern black prosperity gospel and hip-hop culture) and highlights key emblematic figures of that history (from the postbellum black "peddling" preacher to the postmodern hip-hop mogul) that anticipate and inform the spiritual and market modalities of influential mainstream rappers in their "labors" within and against the music industry.

Within the burgeoning field of hip hop and religion, scholars have studied the multivalent utilizations of religion in rap music-whether an interpretation of religious rhetoric as 
expressions of rappers' existential crises (Dyson, Between; Dyson, Holler; Pinn), a deconstruction of rappers' self-aggrandizing uses of religious tropes (Miller, Religion), or a survey of the diversity of rappers' religious worldviews (Miller, "Promiscuous"; Sorett). ${ }^{3}$ This essay provides a new reading of the intersections between religion and rap music in its genealogical consideration of how black laborers' orientations to the market-from the antebellum slave market to the contemporary music industry-have informed their consequent articulations of race and religion. Indeed, of all modern genres of popular music, mainstream rap music remains unique for its artists' seemingly self-reflexive obsession with verbalizing to consumers their relationships to the market or "rap game." While artists of other genres such as rock tend to obscure their negotiation with the commodifying forces of the market in order to present themselves as romantically "authentic," many rappers authenticate themselves to consumers by demonstrating to listeners their successful "hustle" of the music industry (Hess; McLeod; Negus; Quinn). Since Niggaz Wit Attitudes's (NWA's) hyperrealistic and hyper-commercial responses to the post-industrial urban realities of the 1980s, the most successful rap careers have often operated by a market strategy that ironically and ingeniously capitalizes upon conditions of capitalist underdevelopment and racial inequality-even resulting in the emergence of veritable hip-hop "moguls" (for hip-hop moguls, see Smith). As rapper-turned-CEO Jay-Z quips, "I'm not a businessman / I'm a business, man" (from "Diamonds from Sierra Leone," Kanye West featuring Jay-Z).

In their negotiations with the market, such rappers not only create new cultural and commercial meanings of "authenticity" but of race as well. Whether NWA's "gangsta" in the late 1980s, 2Pac's "thug" of the 1990s, or Jay-Z's corporate "hustler" of the 2000s, rappers' expressions of authenticity dovetail with their expressions of blackness to form commodified packages of "authentic blackness" for consumers of all races. Scholars have typically lamented these "mainstream" rappers' cynical capitulations to late capitalism — as opposed to the rap music of more politically conscious artists such as Public Enemy, A Tribe Called Quest, or the Roots (see Neal, "Up"; Rose). However, such "declension" theories of hip hop and capitalism tend to ignore what R. A. T. Judy identifies as the different systems of meaning that constitute rappers' negotiations with the market. ${ }^{4}$ Judy asserts the ideological difference between the commodified "nigga" of mainstream rap music and the "bad nigger" of slave folklore: "nigga defines authenticity as adaptation to the force of commodification" and "poses an existential problem that concerns what it means (or how it is possible) to-be-human," whereas the "badman and bad nigger pose a moral problem that concerns the structures and relations of humans-their governability" (114). Put another way, rappers' constructions of "authenticity" within the music industry signify what I will refer to throughout this essay as a "regime" of values and meaning that, while related, is ideologically distinct from the regime of values and meaning operating within the slaves' folklore-even as slave folklore itself was fundamentally shaped by the market's commodification of black bodies.

Rather than interpret rap music through static ideological categories-whether "authenticity," "agency," "resistance," or "freedom"- -we need to consider the wide-ranging genealogies of these terms and avoid reductions of certain rappers as embodying a false consciousness or acting as race traitors. ${ }^{5}$ Indeed, scholars' myopic employments of a black "authenticity" or "resistance" can oftentimes reinforce the very ideological paradigms they seek to disprove in the first place. Historian Walter Johnson illustrates, for example, how studies of slave "agency" which attempt to "discover" the basic "humanity" of enslaved blacks 
unintentionally reify nineteenth-century binaries of white humanity/black inhumanity in their basic interpretive premise (Johnson, "On," 114-15). That is, in their mission to disprove white supremacy, such scholars fall into the trap of employing and endorsing the same ontological and epistemological terms that have historically structured white supremacy itself. Instead, we should be mindful of how certain ideological categories-in relation to the material conditions of their epoch-have changed over time. We should consider, in other words, the historic ideological and material conditions from which black men and women since slavery have formulated their ideals of "authenticity" (and so on) and resist the teleological application of a static definition of any such term.

This essay thus acknowledges yet moves beyond political critiques of certain rappers as uniformly reflecting neoliberal values in order to argue that the regimes of values and meaning in their music are not completely exhausted by or subsumed within neoliberalism. ${ }^{6}$ Instead, this essay explores how black laborers' orientations to the market-from slaves selling vegetables at the local market to contemporary rappers selling commodities of blackness in the music industry-represent more than black simulacrums or internalizations of white bourgeois values but revisions and transformations of those values as well. In other words, this essay demonstrates how the unique articulations of market and religion in rap music represent a genealogy of ideological categories such as authenticity and freedom whose roots can be traced to slavery.

In what follows, this essay begins with the concomitant births of the modern black prosperity gospel and hip-hop culture and establishes the key ideological categories of market and spiritual "freedom" and "authenticity" at work in the religion and music of T. D. Jakes and Jay-Z. Next, this essay offers a previously unexplored historical genealogy of Jakes' and Jay-Z's complicated religio-economic regimes of value and meaning, from the in/formal economy and religion of the slaves to the postbellum era of black peddling and celebrity preachers. Finally, this essay returns to the present and concludes with a consideration of new generations of hip-hop artists who, in the genealogical tradition of Jay- $Z$, have created in their music new articulations of market and religion.

\section{The Concomitant Births of the Modern Black Prosperity Gospel and Hip-Hop Culture}

The "rapid rise of blacks to the middle and upper classes" occurred "so suddenly" during the "burgeoning consumer culture" of the 1980s that new black "megachurches" arose in cities nationwide to accommodate them (Lee 100). Unlike traditional black Protestant churches, these black "megachurches" fulfilled the specific needs of black "suburbanites" who, "fueled by the post-Civil Rights decline in restrictions on housing, increase in opportunities for education, and better paying jobs," migrated from urban areas stricken by the post-industrial effects of poverty and violence (Tucker-Worgs 4, 44-45). Self-fashioned as veritable "corporate headquarters," black megachurches produced a form of black religion that reflected their congregations' economic status (Bowler 102-03). In what we recognize today as the modern black prosperity gospel, poverty itself thus became a symptom of unbelief-rather than systemic inequality-which required a spiritual solution. In order to realize the blessings of health and wealth awaiting them, believers evince an active faith (such as mental affirmation and financial tithing) in God's universal spiritual laws that govern their socioeconomic successes and failures (Bowler; Harrison; Walton). In other words, 
God's covenantal promises of material abundance dictate the universal laws of the Smithian market so that believers simply lay claim to the former in order to reap the benefits of the latter. As Leroy Thompson, African-American pastor of the Word of Life denomination, preaches, "[Jesus] took your place in poverty so you could take His place in prosperity" (qtd. in Bowler 95). Thompson rehearses a fundamental doctrine of the modern black prosperity gospel: the translation of the believer's spiritual freedom from sin into a market freedom from poverty.

Indeed, the postmodern generation of black prosperity preachers like T. D. Jakes offer not only spiritual guidance to their members but also entrepreneurial mentorship in the commodity form of self-help books, DVDs, television programs, and more. CEO of a multimillion dollar empire, Jakes attributes his spirituality as key to his victory over poverty:

I broke the spirit of poverty over my house by giving my tithes and giving my offerings. I beat the devil out of my checkbook and pleaded [Christ's] blood over my finances. I scraped and crawled my way up out of poverty and into God's prosperity by doing what God said to do! And you can too. (Qtd. in Lee 117)

Jake seamlessly weaves together spiritual principles of prayer with market principles of hard work: "poverty" is both a "spirit" to be defeated through Christ's "blood" and an economic state to be "crawled out of." Jakes thus maintains multiple religious and market modalities: "I own three companies. I've got a production company. And entrepreneurial pursuits are very, very important to me, to my culture, to my family, to my community, and yet I'm still a preacher" (qtd. in Lee 142). Jakes sees no contradiction in his negotiation between his identity as a black entrepreneur and a black preacher. As an African-American model to his "culture," "family," and "community," Jakes' "authenticity" as a successful black businessman validates his "authenticity" as a black preacher. His blackness, in other words, is comprised of distinct yet entwined religio-economic regimes of values and meaning that-though shaped by the ethos of late capitalism-operate in triangular negotiation with it as well.

Yet the revision of spiritual as market freedom within the modern black prosperity gospel can also tend to relegate race as a human characteristic to be transcended altogether. As the testimony of one African-American female member of a Word of Church faith reveals,

For me, as an African American woman, I felt like I was no longer put in a box ... I was a child of God first who happened to be African American ... I didn't feel limited by the color of my skin ... [or] by people's stereotypical views of me as a African American woman ... I wasn't in this "what The Man does to you," you know, The White Man-it wasn't about that. It was about my relationship with God and what God has promised me, and me saying I'm going to live those promises. (Qtd. in Harrison 25-26)

The interviewee bases her newfound liberty from the "box" of race/racism upon her post-racial identity as a "child of God." Her spiritual freedom, buttressed by the market freedom "promised" by God's universal laws, allows her to-so to speak-escape the historical oppression of African-American people. As someone who "happened to be African American," she does not invest spiritual or material meaning in her blackness but expresses a transcendence from blackness itself. Such a belief in the reality-bending power of spiritual freedom reaches its apex in Creflo Dollar, who preaches that believers are "super human beings [who] posses[s] supernatural, creative power" (qtd. in Walton 150). Dollar goes as far as to call believers "gods" themselves: 
I am going to say to you right now you are gods, little g. You came from God and you are gods. You are not just human, the only human part about you is this physical body that you live in.

(Qtd. in Walton 151)

As with the interviewee just cited, Dollar's valorization of the god-like status of (black) believers results in the transcendence of believers' "spiritual heritage" over their "racial heritage" (Mumford 226).

A "counternarrative to black middle-class mobility", hip-hop culture conversely emerged from the devastating aftermath of "white (and black) flight" from former industrial centers and urban renewal policies that led to the "massive relocations of economically fragile people of color" (Neal, "Postindustrial" 363; Rose; Chang). If members of black megachurches solved the "sin" of poverty through faith in universal spiritual laws, many of the hip-hop generation found an "attractive" "counter to poverty" in the budding crack cocaine industry (Neal, "Postindustrial" 369). Instead of using their illicit profits to "build" a "foundation" for "legitimate wealth," black youth "invested in material icons of wealth" such as "cars, cellular phones, jewelry, and au couture fashions" (Neal, "Postindustrial" 369). That is, young black sellers and producers of crack cocaine founded their informal economy upon a desperate exploitation of the impoverished needs of their communities. They thus sought a modicum of equality, wealth, and power within the same market writ large that relegated them to their positions of inequality, poverty, and powerlessness. In their conspicuous consumption, they invested their blackness with materialistic values of excess, and in their drug trade they created a street ethics that rewrote Smithian market authenticity as illicit market activity.

It is no surprise, then, that the "hustler" identity of the drug dealer led to the rise of the hip-hop hustler who produced and sold blackness by the same logic of the informal economy of the ghetto. For these hip-hop artists, the "production of exploitation culture"- "using whatever titillating subject matter is at hand and carving out a niche market for its sensational fare"-became a "source of credibility" or authenticity (Quinn 39). As Eazy E, a founding member of NWA, reasoned, "I took my street knowledge, whether it was from dealin' or hustlin' or whatever, I took it and brung it to the record business. You take that same knowledge you have of how to sell dope and apply it" (qtd. in Quinn 58). Yet unlike the crack cocaine industry, the rap music industry afforded avenues to wealth that went far beyond gold chains and teeth. As a reversal of T. D. Jakes-or, perhaps more accurately, as the other side of the same coin-some hip-hop artists increasingly capitalized upon other market opportunities (fashion, restaurants, endorsements) to become CEOs of their own businesses.

Of all hip-hop artists, Jay- $Z$ stands to this day as the exemplar of the hip-hop mogul. Since his first album in 1996 (Reasonable Doubt) to his most recent in 2017 (4:44), Jay-Z has valorized the market-both "informal" (crack cocaine industry) and "formal" (music industry) - as the only pathway to true freedom in a world of racial inequality. Like NWA before him, Jay-Z carries over his former success as a drug dealer ("I sold it all, from crack to opium") into his vocation as a successful rapper ("We treat this rap shit just like, handlin' weight") ("Regrets"; "Rap Game"). Jay-Z views his "hustle" in both markets as one and the same: that is, just as the informal economy of the drug trade was founded upon conditions of racial inequality, Jay- $Z$ portrays the "formal" economy of the music industry as founded upon the racial exploitation of black artists. He equates owning the masters of his musical property as a material-symbolic gesture of "freedom" from slavery and warns other black artists to "own your masters, slaves" ("No Hook"). True to his word, in his negotiation to 
become Def Jam's CEO in 2005, Jay-Z gained ownership of his musical catalogue, becoming at once his own master/CEO and owner of his masters/music. ${ }^{7}$

Though warranted, the label of neoliberalism upon Jay- $\mathrm{Z}$ can thus elide the history of oppression which informs his unabashed proclamation of "financial freedom" as his "only hope" ("Story of O.J."). Jay-Z "justif[ies]" his "thug"—his endless pursuit of profit—as the simple "play[ing]"of "the hand" he was "dealt" ("Justify"). He operates according to what he perceives as market society's denial of a true black authenticity to him and other black artists, celebrities, and athletes. In "The Story of O.J." Jay-Z muses: "Light nigga, dark nigga, faux nigga, real nigga / Rich nigga, poor nigga, house nigga, field nigga / Still nigga, still nigga." Jay- $Z$ asserts that black artists are unable to escape the categories of blackness constructed by the market since slavery-from the antebellum "house" and "field" "nigga" to the modern "rich" and "poor" "nigga." In response to the absence of a true black authenticity, Jay-Z proclaims his capitalist exploitation of these commodified forms of blackness as his own form of black authenticity: "I'm a field nigga ... I'ma play the corners where the hustlers be." In other words, Jay- $Z$ does not internalize the stereotype of a "field nigga" but utilizes it in order to "hustle" the music industry.

Notably, Jay-Z expresses his market freedom as a postmodern "field nigga" and "hustler" as a form of spiritual freedom. Yet unlike the correlation of universal spiritual and market laws in the modern black prosperity gospel, Jay- $Z$ deifies the market itself as the only source of salvation in a godless world. In a song targeted at former adversary rapper Nas, Jay-Z equates him with what he perceives as the inauthenticity of black prosperity preachers:

Can't y'all see that he's fake, the rap version of T. D. Jakes

Prophesizin' on your CDs and tapes

Won't break you a crumb of the little bit that he makes

And this is with whom you want to place your faith. (Jay-Z, "Blueprint 2")

A more socially and politically "conscious" rapper than Jay-Z, Nas has portrayed himself throughout his career as "God's Son," a nod to his self-assigned role as a "prophet" of the streets. In "The Cross," for example, Nas raps: "I carry the cross / If Virgin Mary had an abortion / I'd still be carried in the chariot by stampedin' horses ... / For you rappers, I carry the cross." In castigating him as the "rap version of T. D. Jakes," Jay-Z questions Nas' religio-economic authenticity as a Christian and black artist and, by extension, Jakes' association of market with spiritual freedom. Instead, in his sacrilegious titles such as "JayHova" - a play-off of Jehovah-Jay-Z has repeatedly glorified the salvific pathway of the market. Jay-Z's rhetorical deification of himself, though, should not be understood as mere self-aggrandizement. Rather, Jay-Z's declarations as "God in the flesh" must be squared with his pronouncements of a godless world where "Jesus can't save you" ("Heaven”; "Empire"). In the absence of a spiritual savior who can heal the sin of poverty, Jay- $Z$ champions not simply himself but-more importantly—his fundamental market identity as a secular savior to economic inequality: “That's why they call me "Hova / I'm far from being God / But I work goddamn hard" ("Breathe"). In other words, Jay-Z does not literally claim to be divine but deifies the market itself, which affords him a quasi-spiritual freedom.

Jay- $Z$ thus represents the extreme ideological culmination-whether the apogee or nadir-of antebellum ideological categories of market freedom and authenticity. In "Legacy," as the hook itself repeats "Legacy, Legacy, Legacy, Legacy / Black excellence baby...," Jay-Z announces the ultimate aim of his market endeavors: "We gon' start a society within a society." His desire to create a "society within a society" through his in/formal market activities 
stand as nothing less than the postmodern evolution of many enslaved peoples' market activities within the larger economy of slavery: from slaves as commodities producing and selling commodities to black artists as exploited commodities producing and selling commodities of themselves Likewise, Jay-Z's attempts to transform the bourgeois values of late capitalism into "black excellence" stands as nothing less than the neoliberal evolution of the attempts of antebellum free black activists to transform the incipient bourgeois values of the market revolution into black "respectability."

\section{The In/Formal Economy of Slaves and Free Blacks}

For slaves, both God and the market offered competing-yet sometimes entwined-ways of negotiating with and disrupting slavery's commodification of them as their masters' property. Within the master's overarching economy, an informal slave economy existed whereby slaves could grow food for subsistence and sale, hire themselves out for profit, and work as quasi-wage laborers for other whites (Berlin and Morgan). Though most slaves did not earn enough to purchase their or their families' freedom, the communal and psychological implications of the little profit they did accumulate went far beyond small improvements to their material conditions (McDonald). Communally, owning property could form ties of kinship amongst slaves with no ostensible familial relations (Penningroth). Psychologically, tending crops, raising animals, walking to local markets, and selling one's labor to nearby farmers gave certain slaves a taste of independence that openly flouted the founding tenet of slavery (Berlin and Morgan; Campbell; Egerton). Indeed, the same law that deemed slaves as property also mandated that all men and women could have "property in goods, notwithstanding he is called a slave" (qtd. in Walker 36). In other words, within the market logic of slavery, property could own property. ${ }^{8}$

Beyond its basic contradiction of slavery's denial of black humanity, the informal slave economy more significantly created new modalities for what it meant to be an enslaved black man and woman-modalities forged from Western (and African) ideological categories of authenticity and freedom. In their tireless depictions of slavery as a benevolent economic alternative to the wage system of the North, ideologues of the Old South frequently contrasted the supposed familial bond between master and slave to the exploitative contract between laborer and capitalist (Davis 217-34; Watson). In the master's world, the Athenian model of "positive" republican freedom was the white male citizen who-free from the indignity of menial labor-pursued loftier intellectual goals and civic responsibilities. In short, white masters authenticated themselves by the black slaves they owned. For Northern "free soil" politicians and abolitionists, the model of "negative" market freedom was the everyday citizen who-driven by the dignity of self-interest-could produce and consume without any unjust encumbrances (Foner). ${ }^{9}$ Such wage laborers conversely defined their "authenticity" by their ability to sell their labor to whomever they pleased. In contradistinction to the fantasy of their masters' classical ideals, many slaves' access to the market-and its cash nexus-gestured towards a similar market regime of values and meaning. In other words, many slaves experienced a "negative" market freedom and developed incipient market values of "authenticity" that, while symbiotically and paradoxically attached to their master's economy, conflicted with their masters' valorizations of a "positive" republican freedom and civic virtue. 
The findings of the 1858 South Carolina Colored Committee speak to the informal slave economy's ideological disruption of the master's economy: "Slaves are permitted to go at large, exercising all the privileges of free persons, making contracts, doing work and in every way being and conducting themselves as if they were not slaves" (qtd. in Walker 79). The "freedom" in this description of slaves as "free persons" suggests the ways in which the negative freedom of many slaves to produce, sell, and consume commodities challenged fundamental ideological terms of the master's economy. For if blackness within the master's regime symbolized the enslaved opposite of the white male citizen who possessed republican freedom and practiced civic virtue, blackness within the regime of the slave's informal economy symbolized the slave who possessed market freedom and practiced destabilizing market values of self-possession and self-interest. It is important to note, however, the limitations of the ideological potentialities of the slave's market activities, for slavery in the South remained a system governed by the threat and application of sheer violence. ${ }^{10}$

In the North, on the other hand, free black activists converted the ideology of the market into a formal political resistance against slavery. Insofar as the nineteenth-century market revolution "created an ideological atmosphere congenial to the destruction of slavery," many black leaders vocalized their attack against slavery through the language of the market (Rael 14). They heralded "respectability," thrift, and hard work as symbolic keys to defeating the self-enclosed cycle of white supremacy: that being the unwarranted propagation of negative black stereotypes and consequent legislation restricting black economic and political opportunity. A reflection of Smithian values of market "authenticity" and "freedom," the term black "respectability" encapsulated a "set of rules that promised the rewards of success without the need for falsity, the comforts of sincerity without the sacrifice of gain" (Rael 28). By that same market logic, these black leaders defined racial prejudice as an inauthentic "nonmarket element" that violated the post-racial equality of the wage system (23). Though their belief in the power of self-interest to defeat personal and systemic racism may seem misguided to us - particularly through the predominant lens of Marxism - we should not forget Marx’s own historical maxim: "Men make their own history, but they do not make it just as they please; they do not make it under circumstances chosen by themselves, but under circumstances directly found, given and transmitted from the past" (595). For many slaves and free black activists, the respective material and ideological "circumstances" of the informal slave economy of the South and the free market of the North informed their attempts to "make their own history." In that vein, Patrick Rael describes Northern black activists as "cofabricators" of a "bourgeois order" whose "words and ideas played critical roles in contesting the meanings of race, class, and gender in America"; to them, "racial uplift and complete human equality were the meaning of bourgeois values" (37). In other words, these enslaved and free black men and women did not simply imbibe or internalize a "white" regime of values and meaning; rather, they arguably transformed market categories of "freedom," "authenticity," and "race" itself in a manner that challenged the prevailing sociopolitical and legal order.

\section{The Sacred World of the Slaves}

During the tent revivals of the 1830s and 1840s, Christianity became an alternative means for many slaves to challenge the system of slavery. Their religion acted as an emotionally, psychologically, and culturally self-preserving canopy from the commodifying forces of 
the slave market (Genovese; Matthews; Raboteau). As Lawrence Levine summarizes, "Slave music, slave religion, slave folk beliefs - the entire sacred world of the black slaves-created the necessary space between the slaves and their owners and were the meanings of preventing legal slavery from becoming spiritual slavery" (80). However, Levine's stark ideological distinction between the slaves' and masters' worlds tends to ignore the dialectical relationship between slavery and slave religion. That is, while Levine is correct in his observation that "slavery was never so complete a system of psychic assault that it prevented the slaves from carving out independent cultural forms," we need to consider how the "psychic assault" of slavery's market logic shaped the slaves' "independent cultural forms" (30). As one freedman related concerning the origin of a spiritual: "My master call me up and order me a short peck of corn and a hundred lash. My friends see it and is sorry for me. When dey come to de praise meetin' dat night dey sing about it" (qtd. in Raboteau 246). This ex-slave's brutal punishment under slavery-his designation as the extension of his master's will-informed his fellow enslaved community's production of religious culture.

It is because the slaves' religious culture was shaped by the very commodification of their bodies that their sacred music, rituals, and beliefs constituted forms of black "labor"artistic and cultural — that operated against their masters' ownership of their bodies and labor. Ronald Radano thus argues that the musical practice of slaves, in its paradoxical constitution as the "property of a property," represented a "property-form and economic value" that "exist[ed] within and against [the] antebellum market exchange" (177-78). That is, slave music's "perceived qualities of physical excess and embodiment" made it a "new form of Negro ownership" that "exceeded complete possession even by those whites who owned slaves" $(177,194)$. Fundamental to the subversive form of slaves' musical practices, the very ideological content of the slaves' sacred music also represented a spiritual regime of values and meaning in opposition to the market logic of slavery.

Like the market freedom of the slaves' informal economy, the spiritual freedom of the slaves' religion offered new modalities for what it meant to be a slave, to be human, and to be black. Certainly, as historians have discussed, the "freedom" of certain spirituals could represent physical and political freedom from slavery (Raboteau 248-54, 290-318). Especially during the Civil War, hopeful slaves and black soldiers sang of a liberty encompassing both spiritual and physical forms: "We'll soon be free (3x) / When Jesus sets me free / We'll fight for liberty (3x) / When de Lord will call us home" (qtd. in Raboteau 248). Likewise, in another spiritual, the verse "No more slavery in de kingdom" was later added at the war's conclusion to a song ostensibly about other-worldly anticipation: "Dere's no rain to wet you / O yes, I want to go home / Want to go home" (qtd. in Allen et al. 46). Clearly, then, during the emancipatory atmosphere of the late antebellum era, many slaves could accentuate more explicitly the political implications that had always discreetly been core to their religion. However, our understanding of the secular dimensions of the slave's sacred worldviews should not overlook how the slaves' religion itself comprised a spiritual ideology at odds with the materialistic ideology of the slave market which categorized them into fungible commodities of sex, weight, height, skin color, and job title (for slave market, see Johnson, Soul). Songs like "Go Down, Moses" illustrate not simply, or even most importantly, the desire for physical deliverance from slavery but also the recognition of a spiritual deliverance and liberty already claimed within slavery. When slaves sang "My sin is forgiven and my soul set free," they expressed a spiritual modality-what theologian James Cone describes as an ontological "somebodiness" - separate from yet shaped by their physical modality as 
the slave of their master (Allen et al. 2; Cone 91). That is, the spiritual logic of the unbeliever's salvation from sin and freedom in Christ operated against yet within the market logic of the slave's subhuman commodity status and bondage to Man. The slaves' predominant identification as the children of Israel, then, not only spoke to their temporal desires for freedom in the Promised Land (i.e. the North); more fundamentally, it also suggested the new meanings of "freedom," "authenticity," and "race" made available through the medium of a religion shaped by its followers' abject commodification. In their dialectical identifications as God's children and Man's property, slaves proclaimed the spiritual worth of their blackness in contradistinction to its material worth to their masters. They distinguished the authenticity of their relationship to "Massa Jesus," their "bosom friend," to the injustice of their relationship to their earthly masters (Allen et al. 57).

Here, it is important to contend Orlando Patterson's long-standing assertion in Slavery and Social Death (1982) that slave religion ritualistically assimilated the socially dead slave into the master's society. ${ }^{11}$ Patterson founds his argument on a tenuous distinction between two Pauline metaphors describing Christ's salvific relationship to believers: Christ as Redeemer and Christ as King. Patterson views these two titles of Christ as representing two contradictory theologies: the former based upon the spiritual freedom of the sinner from sin and the latter based upon the spiritual bondage of the sinner to Christ. Patterson thus sees the Apostle Paul's "ethic of judgment" (Christ the Redeemer) as allowing slaves to "find salvation and dignity" under the degradations of slavery and Paul's "ethic of judgment" (Christ the King) as allowing slaves to "com[e] to terms with ... all authority relations" (75-76). In short, then, Patterson deems the spiritual freedom of slave religion as enforcing a spiritual bondage to Christ and, by extension, a physical bondage to earthly masters. Yet the biblical verses in question, when considered in the full context of Paul's motif of spiritual freedom and slavery, do not support what Patterson interprets as a hegemonic slavery to Christ and Man.

Instead, Paul's multivalent uses of categories of "freedom" and "slavery" serve as a warning to believers who- to apply the types of liberty discussed earlier in this essay-misguidedly equate their "positive" freedom in Christ (the higher good of righteousness) with the "negative" freedom to sin without restriction. Because it is important to consider, as much as possible, the coherent theological structure undergirding Paul's metaphors, I quote the biblical passage at length:

Shall we sin because we are not under the law but under grace? Certainly not! Do you not know that to whom you present yourselves slaves to obey, you are that one's slaves whom you obey, whether of sin leading to death, or of obedience leading to righteousness? But God be thanked that though you were slaves to sin, yet you obeyed from the heart that form of doctrine to which you were delivered. And having been set free from sin, you became slaves of righteousness. I speak in human terms because of the weakness of your flesh. For just as you presented your members as slaves of uncleanness, and of lawlessness leading to more lawlessness, so now present your members as slaves of righteousness for holiness. For when you were slaves of sin, you were free in regard to righteousness ... But now having been set free from sin, and having become slaves of God, you have your fruit to holiness, and the end, everlasting life. (New King James Version, Rom. 6:15-22)

First, Paul qualifies that his unorthodox uses of freedom and slavery are imperfect earthly metaphors- "human terms"- that are not intended to reflect some one-to-one spiritual reality. (Indeed, how could they?) Second, Paul's descriptions of believers as "slaves of righteousness" and "slaves of God" are rhetorically meant to differentiate, in hyperbolic language, 
the types of freedom experienced by the believer and the unbeliever. The "negative" freedom of the unbeliever consists of a slavery to sinful actions, a simultaneous unhindered freedom to sin yet slave-like inability to commit righteous acts (i.e. the higher good). That is, Paul describes the unbeliever's "freedom" to commit only acts of sin-and not acts of righteousness as well-as really a form of "slavery." Conversely, the "positive" freedom of the believer consists of a slavery to the righteousness of God, a simultaneous freedom to commit sinful acts yet also-and here lies Paul's hyperbolic emphasis-commit acts of righteousness. That is, Paul describes the believer's "freedom" as representing a greater range and higher ideal than the unbeliever's. Finally, then, Paul's intent in depicting the believer as a "slave" is to remind believers of the greater responsibility and accountability that comes with their greater "positive" freedom in Christ as opposed to their former "negative" freedom in sin. (Note Paul's command to believers to "present" themselves as "slaves of righteousness for holiness" - to choose, that is, between acts of sin and acts of righteousness).

It is therefore a glaring misinterpretation of Pauline theological metaphors that informs Patterson's reduction of the spiritual freedom of the slaves' religion into an ideological tool of the ruling class. The believer's "freedom" from sin in Christ the Redeemer does not contradict but dovetails with the believer's willing "slavery" to Christ the King; both metaphors, in other words, depict two different dimensions of the believer's "positive" spiritual freedom. At a more historically concrete level, are we to believe that thousands of enslaved black men and women viewed their freedom in Christ as another form of slavery to their white masters? Indeed, enough scholarship has illustrated that slaves differentiated their religion from their masters', from the covert services of the "invisible institution" to the public establishment of autonomous black churches. ${ }^{12}$

\section{From Peddling to Celebrity Preachers}

Although Sunday could be a day either to visit the local market or to attend church, God and the market were not completely distinct ways of knowing and being for many slaves. Certainly some religious slaves shunned the market activities of others, especially when illicit items such as liquor were bought. It is more reasonable to assume, however, that many enslaved black men and women unproblematically embodied multiple identities as slaves of their masters, as quasi-independent laborers, and as children of God. Indeed, the market freedom of the slaves' informal economy both juxtaposed and-in some ways-reinforced the spiritual freedom of their religion. For instance, many slaves used the small profits they earned from their independent labor to purchase church attire which was nicer than what they wore during the week. In that sense, they invested spiritual value in their material possessions (Penningroth 99-100).

At a deeper ideological level, slaves also developed what travel writer Frederick Olmsted described during his tour of antebellum Virginia as a "negro system of ethics":

that the result of labor belongs of the right of the laborer, and on this ground, even the religious feel justified in using "Massa's" property for their own temporal benefit. This they term "taking", and it is never admitted to be a reproach to a man among them that he is charged with it, though "stealing", or taking from another than their master, and particular from another, is so. (Qtd. in Levine 124)

The slaves' discrepancy between "taking" from their masters and "stealing" from their fellow slaves marked a blurring between market and spiritual ideological categories. That is, slaves 
conjoined the market value of "authenticity" (the self-interest of independent labor) with the spiritual value of "authenticity" (the spiritual versus material worth of their blackness). They buttressed their market freedom (the liberty to sell and enjoy the fruits of one's labor) with their spiritual freedom (the liberty of Christ's redemption from sin). The resulting "negro system of ethics" constituted a religio-economic worldview wherein slaves condemned their masters' economy and religion as a violation of their material rights as self-possessing laborers and spiritual status as children of God.

Many slaves, then, negotiated between the ideological triangulation of their market modality, religious modality, and commodified modality (as their master's property). The failure to distinguish these distinct, though interrelated, regimes of values and meaning leads to misguided assessments of the slaves' differentiation between "taking" and "stealing" as evidence of the "weaken[ing] of their self-respect" - as if slaves simply internalized their masters' code of ethics (Genovese 609). Rather, to employ Rael's term from earlier, slaves "cofabricated" the market and religious values of their masters in order to formulate their own religio-economic code of ethics that, while shaped by their masters', operated against it as well.

Following Emancipation, many ex-slaves' articulations of market and religion became increasingly entwined in unprecedented ways. In the aftermath of the failures of Reconstruction, many black leaders-namely, preachers-saw in their religious heritage a business opportunity to gain equal footing in American society. With the rapid development of the consumer market in the late nineteenth century, ex-slaves continued to bolster their religious identity through purchases of an increasing variety of goods such as fashionable clothes, pictures, and books-even as white storeowners often sold black customers inferior products or refused them sufficient credit. Likewise, despite the commodifications of blackness in products such as "Nigger Head Tobacco," some black religious leaders capitalized upon Northern manufacturers' interest in a growing black consumer base as a means to garner profit. They became "peddlers" who willingly commodified their religious authority in order to advertise domestic merchandise (books, paintings, health products) to their congregations. The motivations of peddling preachers were both altruistic and self-driven: to support burgeoning black institutions, to introduce their members to a wider market of goods, and to provide themselves with supplementary incomes (Giggie 96-136). If the antebellum black preacher acted as a mediator between white society and the slave community, balancing the hegemonic expectations of slave owners with the liberatory desires of slaves, the postbellum black preacher acted as a new mediator between the commercial world of white society and the ex-slave community, balancing the commodifying forces of the market with the authenticity of black religion.

Perhaps unsurprisingly, some newspapers began questioning the integrity of some black preachers who appeared more interested in peddling products than in saving souls, especially as print advertisements gradually replaced face-to-face contact. Ida B. Wells summed up the growing suspicions of many black communities: "Isn't this rather a new idea-this using our pulpits as an advertising medium for soap?" (qtd. in Giggie 128). One advertisement in the 1895 edition of the Baptist Vanguard exemplifies the ever-tenuous blurring of market and spiritual modalities within the practices of these peddling preachers. In an ad for a panacea called "Mexican Mustang Liniment," the Reverend F. M. Jacobs testifies-alongside a meticulous portrait of him - that the product "has proven an indispensable thing for the eradication of pain, bruises, and especially for neuralgia, of which my [Jacobs'] wife was 
a constant sufferer" (Giggie 130-31). Still, notwithstanding the probable duplicity of such peddling preachers, others sought to counteract prevailing designations of black religion as a signifier of ex-slaves' inability to enter American society. They attempted to counter society's association of race with slothfulness by establishing a form of black religious capitalism. ${ }^{13}$

Decades later, during the "race records" industry of the 1920s and 1930s, some black preachers in the North recorded and sold their sermons to a black urban consumer base constantly growing from migration. In the tradition of earlier peddling preachers, men like the Reverend James M. Gates commodified their vocation as preachers, becoming in turn "commercial icon[s]" and the first black religious "celebri[ties]" (Martin 2). Though they frequently condemned the corrupting influences of market society, black celebrity preachers like Gates ironically gained their sheer popularity and financial success from the market itself. Sales of Gates' 1926 recordings "Death's Black Train is Coming" and "I'm Gonna Die with the Staff in My Hand" surpassed the contemporary records of blues artists-for example, Ethel Water's "Take What You Want/We Don't Need Each Other Anymore" and Bessie Smith's "Lost Your Head Blues/Gin House Blues" (sales of over 50,000 records for Gates compared to 17,400 for Waters and 21,325 for Smith) (Martin 103). Besides the attractiveness of his downhome folk style to black consumers newly migrated from the South, Gates evinced shrewd business knowhow: he secured the copyright to his popular sermons and thus collected royalties from record sales-in addition to lump sums for the recordings themselves-that most other artists did not receive. For these black celebrity preachers, financial prosperity became a form of authenticity that did not compromise but rather evidenced God's favor.

These peddling and celebrity black preachers represented new articulations of market and religion since the era of slavery: from slaves who championed a spiritual freedom against the commodifying forces of the market to former slaves who commodified that same religious heritage in order to negotiate with the commodifying forces of the postbellum market. Their conflations of spiritual and market regimes of values and meaning paved the way for the twin figureheads of black religio-economic modalities that emerged from the aftermath of post-industrialism: T. D. Jakes and Jay-Z.

\section{The New Generation(s) of Rap Music}

This essay concludes with a consideration of rappers who have created in their music new articulations of market and religion: Kanye West, Kendrick Lamar, and Chance the Rapper. Currently three of the most celebrated, best-selling rappers in the music industry, West, Lamar, and Chance represent-respectively-three successive generations of rappers since Jay-Z. Each has expressed throughout his entire career distinct yet entwined categories of spiritual and market freedom and authenticity.

Since his debut album, West's religious heritage has informed his orientation to the market. On The College Dropout (2004), West bolsters a critique of capitalism with a call for religious devotion. In "All Falls Down," he captures the perils of black youth who seek personal fulfillment through materialism:

We shine because they hate us, floss 'cause they degrade us

We trying to buy back our 40 acres

And for that paper, look hoe we a stoop

Even if you in a Benz, you still an nigga in a coupe. 
West connects the failures of Reconstruction to provide reparations to ex-slaves to the materialistic values of the hip-hop generation. He bemoans how capitalist underdevelopment causes many black youth to "hate [themselves] and love [their/white] wealth." Yet in the final verse, West nonetheless embraces the bourgeois values of the market: "But I ain't even gonna act holier than thou / Cause fuck it, I went to Jacob with twenty-five thou[sand] / Before I had a house and I'd do it again." Like Jay-Z before him-whom West calls a "big brother"-West's recognition of market society's self-enclosed categorization of black artists as "still a nigga" only serves to authorize his conspicuous consumption ("Big Brother").

However, West also represents a signal departure from Jay- $\mathrm{Z}$ in his expressions of dual market and religious modalities. In "Jesus Walks," West champions his personal faith as a spiritual balm for the woes of the black informal economy: "To the hustlers, killers, murderers, drug dealers, even the strippers / (Jesus walks for them) / To the victims of welfare for we livin' in Hell here, hell yeah / (Jesus walks for them)." (Notably, in the three music videos released for the song, an African-American actor plays the role of Jesus who talks through the streets of the ghetto.) Indeed, West presents the song itself as an offering to God:

They say you can rap about anything except for Jesus

That means guns, sex, lies, videotape

But if I talk about God my record won't get played, huh?

Well if this take away from my spins

Which'll probably take away from my ends

Then I hope this take away from my sins.

West brokers his potential loss of revenue in releasing a religious rap single with the hope for redemption from the corruption of the market. His religious authenticity as a Christian does not replace or merge with his market authenticity as a materialistic rapper but co-exists with it in uneasy tension.

In Late Registration (2005) and Graduation (2007), West reaffirms this paradoxical articulation of market and religion-that is, his simultaneous sacred critique and secular valorization of capitalism. He contemplates in "Diamonds from Sierra Leone (Remix)":

I thought my Jesus-piece was so harmless

Til' I seen a picture of a shorty armless

And here's the conflict

It's in a black person soul to rock that gold

Spend your whole life trying to get that ice...

How can somethin' so wrong make me feel so right?

Likewise, in "Can't Tell Me Nothing," West muses, "I had a dream I could buy my way to heaven / When I awoke, I spent that on a necklace / I told God I'd be back in a second / Man it's so hard not to act reckless." In both songs, West expresses what could be seen as a sacred-profane double consciousness, an internal division as a black artist between his desires for the purity of God and the excesses of the market. ${ }^{14}$ In a world of racial inequality, West desires both a spiritual freedom from the commodification of his blackness and a market freedom to exploit the commodification of his blackness.

In his most recent albums, however, West merges his two conflicting modalities into one new identity: Yeezus. ${ }^{15}$ At a pre-lease listening party for the album of the same name-Yeezus (2013) - West announced to the audience that his new moniker indicated a religious rebirth: "West was my slave name; Yeezus is my God name" (qtd. in McGovern). In "New Slaves," West defines his former status as a "slave": "My momma was raised in the era when 
/ Clean water was only served to the fairer skin / Doin' clothes you would have thought I had help / But they wasn't satisfied unless I picked the cotton myself." West transhistorically connects his mother's experiences under the neo-slavery of Jim Crow segregation to his treatment within the fashion industry as a "new slave." His consequent rebirth as "Yeezus" collapses the tenuous barrier between spiritual and market regimes of values and meaning in his former albums: the suffering (black) Jesus that he posed as for a cover of Rolling Stone transforms into a sacrilegious figure of bacchanalian decadence. In "I Am a God," the hook repeats with frantic urgency:

I am a god

Hurry up with my damn massage (2x)

Get the Porsche out the damn garage

I am a god/ Even though I'm a man of God

My whole life in the hands of God

So y'all better quit playin' with God.

West's status as a god stands as a stark perversion of Creflo Dollar's proclamation of believers as "little g" gods. West transforms Dollar's black prosperity gospel of righteous riches into a neo-gospel of unrighteous riches: from health and wealth to sexual promiscuity and luxury cars. In the second verse, West relays an informal prayer to the sacrilegious savior of his new religion: "I just talked to Jesus / He said, 'What up, Yeezus?' / I said, 'Shit, I'm chillin' / Tryna stack these millions'? I know he the most high / But I am a close high." In his identification as Yeezus, a "close high" to the "most high" Jesus, West does not subordinate his racial heritage for a spiritual one; rather, he both deifies his blackness as Christ-like and reifies his blackness as materialistic excess.

Finally, in The Life of Pablo (2016), West's articulation of market and religion reaches a tipping point of self-implosion. The moniker "Pablo" speaks to the multiple modalities West has juggled throughout his career: as St. Paul the Apostle, spreading the gospel to the world, as Pablo Escobar, seeking the pleasures of the world, and as Pablo Picasso, forging an unholy synthesis between the two. The cover art for the album visually captures these contradictory modalities. Two images are juxtaposed: one of an antiquated black family posing before a small church in their Sunday best, and the other of a topless model posing before a modern urban setting. The title of the album repeats itself down the center, and on both sides of these images an irreconcilable question is presented to the consumer and to West himself: "WHICH / ONE." The rest of the album's tracks reflect this core tension of West's career: in the gospel-infused "Ultralight Beam," West presents the worshipful song as a "God dream" amidst life's difficulties, and in the irreverent "Father Stretch My Hands, Pt. 1," West defines his desire to "feel liberated" in terms of a sexual tryst with a model.

Throughout his three major label albums, Kendrick Lamar has relied upon his personal faith as a source of "real" authenticity amidst the temptations of the ghettos, the music industry, and the celebrity lifestyle. In Good Kid, M.A.A.D City (2012), Lamar casts his autobiographically based rise from young (fictional) gang member to prominent rapper as a spiritual conversion narrative. ${ }^{16}$ In the opening track, the album's young black protagonists-including Lamar-recite the sinner's prayer for salvation: "Lord God, I come to you a sinner / And I humbly repent for my sins" ("Sherane"). The rest of the album, which plays out as an audio documentary of Lamar's life in the Compton ghetto, defines those "sins" as the temptations of peer pressure ("The Art of Peer Pressure"), drug and alcohol abuse (“Swimming Pools"), and gang violence ("m.A.A.d city"). 
Unlike the typical hip-hop rags-to-riches story, Lamar conjoins his secular birth as a rapper with his spiritual birth as a Christian. A reference to Jesus' words to the Samaritan woman at the well, "Sing About Me, I'm Dying of Thirst," heralds spiritual salvation as the answer to Lamar's and, by extension, his generation's hardships. As the hook repeats "dying of thirst," Lamar ponders: "How many sins? I'm running out / How many sins? I lost count." At the song's conclusion, an old female spiritual guide-voiced by the late Maya Angelou-leads Lamar and his friends in the sinner's prayer that began the album. In the final two songs, "Real" and "Compton," Lamar heralds a newfound spiritual freedom to move beyond his past as a teenage gang member and enter his future as a rapper. In the former song, the chorus repetitiously and proudly proclaims, "I'm real, I'm real, I'm really really real," as Lamar's father defines in the form of a voicemail true black authenticity: "Any nigga can kill a man, that don't make you a real nigga ... Real is God, nigga." In the latter song, Lamar carries over his "new faith" into his future endeavor to "harvest the rap artists of NWA" - to follow, in other words, in their footsteps by "translat[ing]" the "[h]arsh realities" of the ghetto into "music."

In To Pimp a Butterfly (2015), Lamar subsequently navigates the temptations of the music industry as a mainstream rapper. Throughout the album, Lamar explores how the commodifying forces of the market attempt to compromise his religious integrity. In the opening track, "Wesley's Theory," titled after the riches-to-rags black celebrity exemplar Wesley Snipes, Lamar equates the materialistic excess afforded by black celebrityhood with the empty promises of Reconstruction: "What you want, a house or a car? / Forty acres and a mule, a piano, a guitar?" In "For Free? (Interlude)," Lamar connects the slave market's exploitation of black labor to the music industry's exploitation of black artists: "Oh America, you bad bitch, I picked cotton and made you rich / Now my dick ain't free." Like Jay-Z and West before him, Lamar understands the transhistorical lineage of the market's commodification of blackness; yet unlike them, Lamar refuses to trade in that commodification of blackness for profit.

Instead, Lamar clings to his faith in his spiritual warfare against the evils of the market. In "For Sale? (Interlude)," Lamar identifies the temptations of the market as the temptations of Satan himself. Impersonated by Lamar in high-pitched ethereal tone, "Lucy"- short for Lucifer-offers Lamar riches and fame in exchange for his spiritual authenticity:

Lucy got million stories

about these rappers that I came after when they was boring

Lucy gon' fill your pockets

Lucy gon' move your mama out of Compton

Inside the gigantic mansion like I promised

Lucy just want your trust and loyalty.

In "How Much a Dollar Cost," Lamar reframes his exchange with Lucy as an exchange with God. In a parable about the dangers of greed, Lamar discovers a terrible truth after refusing to offer a homeless man a single dollar:

He looked at me and said, "Your potential is bittersweet"

I looked at him and said, "Every nickel is mines to keep"

He looked at me and said, "Know the truth, it'll set you free"

"You're lookin' at the Messiah, the son of Jehovah, the higher Power." 
As a hypothetical consequence of Lamar's acceptance of Lucy's offer, Jesus proceeds to warn Lamar: "I'll tell you how much a dollar cost / the price of having a spot in Heaven, embrace your loss." Lamar, then, magnifies the spiritual freedom of his religious modality over the freedom of the market. Indeed, much like West in "Jesus Walks," Lamar considers his musical labor itself as an offering to God in exchange for his redemption from the wickedness of the market. In the EP untitled unmastered (2016), Lamar pleads to God on a track that depicts the onset of the apocalypse and God's consequent judgment of mankind: "I made To Pimp a Butterfly for you / Told me to use my vocals to save mankind for you... / I tithed for you, I pushed the club to the side for you / Who love you like I love you?" ("Untitled 01").

In DAMN (2017), Lamar's answers that rhetorical question with a resounding affirmation of his faith in God amidst the wiles of the market. He again expresses fears over losing his religious authenticity in his growing prosperity as a rapper: "All this money, is God playin" a joke on me? / Is it for the moment, and will he see me as Job? / Take it from me and leave me worse than I was before?" ("Fear"). Yet unlike the tension between spiritual and market modalities in his previous albums, Lamar discovers in DAMN a new articulation of market and religion in the form of the black Israelite religion. No longer in a constant struggle against the market's commodification of his blackness, Lamar avers in "Yah"-a title short for Yahweh-a transcendence over blackness itself:

I'm a Israelite, don't call me Black no' mo'

That word is only a color, it ain't facts no mo'

My cousin called, my cousin Carl Duckworth

Said know my worth

And Deuteronomy say that we all been cursed.

Towards the end of the album, Carl Duckworth himself explains in more detail (in the form of yet another voicemail) the doctrine of the black Israelite religion:

We [defined earlier as "the so-called Blacks, Hispanics, and Native American Indians"] are the Israelites, according to the Bible ... He's gonna punish us for our iniquities, for our disobedience, because we chose to follow other gods that aren't His son, so the Lord, thy God, chasten thee. ("Fear")

Though Lamar has since related in interviews an ambiguous relationship to the black Israelite religion, he nonetheless stands firm in his real-life cousin's controversial explanation of racial oppression as God's judgment against His children's disobedience. Unsurprisingly, Lamar has received criticism for seemingly blaming minorities for the oppression they experience. However, as this essay has demonstrated so far, Lamar's articulation of a religion that transcends race must be considered in relation to his orientation towards the market.

In stark contrast to Creflo Dollar's and Kanye West's similar yet distinct declarations of a black (sacrilegious) prosperity gospel, Lamar's black Israelite beliefs signify a new form of black authenticity—one grounded in black religious mythology-in opposition to the market's categorizations of blackness. ${ }^{17}$ While his former Christian identity, like the religion of the slaves, suggested a spiritual regime of values and meaning at odds with the market logic of the music industry, his latest religious identity as a black Israelite represents a new form of blackness altogether, one based on an ethnic identity—shared with other oppressed races-as the children of Israel. In other words, if the slaves' identification as the children of Israel signaled their recognition of the spiritual value of their blackness (as opposed to its material value to their masters), Lamar's identification as a black Israelite signals his 
recognition of the mythological "worth" of his blackness (as opposed to its commodity value within the music industry). His transcendence of race, then, suggests most fundamentally a transcendence of race-as-commodity.

Finally, in Coloring Book (2016), Chance the Rapper-who describes himself as "Kanye's best prodigy" - celebrates a faith much akin to the modern black prosperity gospel, yet with a signal political difference ("Blessings Reprise"). Released as a free "mixtape" to the public, the album continues his independent, anti-record label approach to the music industry. Chance attempts to avoid altogether West and Lamar's conflicted relationships to the market by upending its profit-driven logic. At the level of market exchange, he counters the commodity of the album with the gift of the mixtape. Chance thus views the disruptive logic of the mixtape form as a type of spiritual freedom in God: "I don't make songs for free, I make 'em for freedom / don't believe in kings, believe in the Kingdom" ("Blessings"). His black prosperity gospel constitutes a definition of "black" as religious integrity from commodification and "prosperity" as God's material blessings outside of the corruption of the music industry.

Furthermore, unlike the post-racial tendencies of the modern black prosperity gospel-that is, its adherents' and teachers' (self-)perceived transcendence above the racial oppression of the "White Man"-Chance likens his religio-material freedom from the music industry to the religio-political revolts of slaves: "Don't believe in signing, I seen dollar signs / Color white collar crime / good God the gift of freedom / Hosanna Santa invoked and woke up the slaves / From Southampton to Chatham Manor" ("How Great"). Chance connects the political significance of his rejection of the capitalist practices of the music industry with the political-sometimes bloody-potential of the religion of the slaves. In that sense, he represents himself as a type of Nat Turner, likening Turner's antebellum rebellion against the capitalism of slavery to his own contemporary rebellion against "Color white [supremacist] collar crime [capitalism]." Elsewhere on the mixtape, Chance rejects the modern black prosperity gospel's doctrinal translation of poverty into a spiritual ailment in his own translation of the "black lives matter" political motto into the religious motto: "Jesus' black life ain't matter" ("Blessings"). Chance revitalizes a prophetic, liberationist legacy within the black (prosperity) gospel. He balances his celebration of black religious materialism with a political condemnation of black suffering.

\section{Conclusion}

On his 2010 album My Beautiful Dark Twisted Fantasy, Kanye West asks: "Is hip hop just a euphemism for a new religion? / The soul music of the slaves that the youth is missing?" As this essay's journey from the religio-economic modalities of the slaves to the sacred-profane modalities of West himself has illustrated, the answer is yes-and more. For in hip hop we not only see the "soul music of the slaves" but the informal market activities of the slaves as well. We see in rap music, in other words, the ever-evolving African-American genealogy of market and religion.

\section{Notes}

1. This essay follows Herzog's definition of the "market" as both constituting "the complex system in which people buy and sell, offering money, goods, labour, time, and abilities" and 
considering the extent to which "societies have, to a greater or lesser degree, become 'market societies"' (1).

2. This essay uses "articulation" in a dual sense: as an expression of interconnected cultural elements and, very broadly following Stuart Hall, as a "reorganization of the elements of a cultural practice" (144-45). It does not, however, follow the ideological and political dimensions of Hall's use of "articulation" as a way to understand how the "State condenses very different social practices and transforms them into the operation of rule and domination over particular classes and other social groups" (121).

3. See also the recent anthologies by Miller and Pin (Hip Hop) and Miller, Pinn, and Freeman (Religion in Hip Hop).

4. For declension theories of art and capitalism, see Taylor (20-43).

5. See Neal ("Postindustrial"; "Up"), Rose, and-for classic studies-Frazier; Berlin.

6. For hip hop as neoliberal, see Spence (19-54).

7. For a history of Jay-Z's entrepreneurial career, see Greenburg.

8. For sake of space, this essay does not consider the interactions of free blacks in the South with the market (see Berlin).

9. For a history of Republican freedom versus market freedom, see MacGilvray. For a history of "positive" versus "negative" freedom in relation to the market, see Herzog.

10. For the sheer violence that governed the economy of slavery-and by implication the slave's informal economy-see Baptist.

11. Patterson defines social death as the "natal alienation" of the slave: "Alienated from all 'rights' or claims of birth, he ceased to belong in his own right to any legitimate social order" (5).

12. For studies on the uniqueness of the slaves' religion, see Alho; Raboteau; Hopkins; Lincoln. The nomenclature "invisible institution" refers to the religious meetings of slaves- "hidden from the eyes of the master" - that were held in the "secrecy of the quarters or the seclusion of the brush arbors" (Raboteau 212).

13. For black religion as a signifier of black inferiority from ante- to postbellum society, see Evans.

14. For a more traditional reading of West as reflecting a double consciousness, see CiccarielloMaher.

15. For a reading of West's religious moniker as an act of self-aggrandizement, see Miller (“God”).

16. While Lamar's father was a member of a gang called "Gangster Disciples," Lamar's own experience with gang culture was by approximation rather than affiliation (Eells). In Good Kid, M.A.A.D. City, however, Lamar fictionally presents himself as a gang member-an autobiographical gesture both to his own father's past and his experiences growing up amidst gangs.

17. For history of the mythology of black Israelite religion, see Dorman. For a history of black religious mythology in general, see Moses.

\section{Acknowledgments}

I would like to thank Bruce Dick, GerShun Avilez, and the anonymous reviewers of this journal for their feedback and incisive criticisms during various stages of this essay.

\section{Disclosure statement}

No potential conflict of interest was reported by the author.

\section{Notes on contributor}

Kevin Pyon is currently an English PhD candidate at the University of North Carolina at Chapel Hill. His research interests include African American history, literature, religion, and music. 


\section{Works Cited}

Alho, Olli. The Religion of the Slaves: A Study of the Religious Tradition and Behavior of Plantation Slaves in the United States 1830-1865. Helsinki: Academia Scientiarum Fennica, 1976. Print.

Allen, William Francis, Charles Pickard Ware, and Lucy McKim Garrison, eds. Slave Songs of the United States. Bedford, Massachusetts: Applewood Books, 1867. Print.

Baptist, Edward. "Toward a Political Economy of Slave Labor: Hands, Whipping-Machines, and Modern Power." Slavery's Capitalism: A New History of American Economic Development. Ed. Sven Beckert and Seth Rockman. Philadelphia, PA: U of Pennsylvania P, 2016. 31-61. Print.

Berlin, Ira. Slaves Without Masters: The Free Negro in the Antebellum South. New York, NY: Vintage Books, 1974. Print.

Berlin, Ira and Philip D. Morgan. "Labor and the Shaping of Slave Life in the Americas." Cultivation and Culture: Labor and the Shaping of Slave Life in the Americas. Ed. Ira Berlin and Philip D. Morgan. Charlottesville: UP of Virginia, 1993. 1-45. Print.

Bowler, Kate. Blessed: A History of the American Prosperity Gospel. New York, NY: Oxford UP, 2013. Print.

Campbell, John. “As 'A Kind of Freeman'?: Slaves' Market-Related Activities in the South Carolina Up Country, 1800-1860. Cultivation and Culture: Labor and the Shaping of Slave Life in the Americas. Ed. Ira Berlin and Philip D. Morgan. Charlottesville: UP of Virginia, 1993. 243-274. Print.

Chance the Rapper. Coloring Book, 2016. MP3.

Chang, Jeff. Can't Stop Won't Stop: A History of the Hip-Hop Generation. New York, NY: St. Martin's P, 2005. Print.

Ciccariello-Maher, George. "A Critique of Du Boisian Reason: Kanye West and the Fruitfulness of Double-Consciousness." Journal of Black Studies 393 (2009): 371-401. Print.

Cone, James H. The Spiritual \& the Blues: An Interpretation. New York, NY: Seabury Press, 1972. Print.

Davis, David Brion. In the Image of God: Religion, Moral Values, and Our Heritage of Slavery. New Haven, CT: Yale UP, 2001. Print.

Dorman, Jacob S. Chosen People: The Rise of American Black Israelite Religions. New York, NY: Oxford UP, 2013. Print.

Dyson, Michael Eric. Between God and Gangsta Rap: Bearing Witness to Black Culture. New York, NY: Oxford UP, 1996. Print.

Print.

Eells, Josh. “The Trials of Kendrick Lamar.” Rolling Stone. 22 June 2015. Web. 12 March 2018. <https:// rollingstone.com/music/features/the-trials-of-kendrick-lamar-cover-story-20150622>.

Egerton, Douglas R. "Slaves to the Marketplace: Economic Liberty and Black Rebelliousness in the Atlantic World.” Journal of the Early Republic 264 (2006): 617-639. Print.

Evans, Curtis J. The Burden of Black Religion. New York, NY: Oxford UP, 2008. Print.

Foner, Eric. The Market Revolution in America: Social, Political, and Religious Expressions, 1800-1880.

Ed. Melvyn Stokes and Stephen Conway. Charlottesville: UP of Virginia, 1996. 99-127. Print.

Frazier, E. Franklin. Black Bourgeoisie. New York, NY: Simon \& Schuster, 1957. Print.

Genovese, Eugene D., and Jordan Roll. Roll: The World the Slaves Made. New York, NY: Random House, 1974. Print.

Giggie, John M. After Redemption: Jim Crow and the Transformation of African American Religion in the Delta, 1875-1915. New York, NY: Oxford UP, 2008. Print.

Greenburg, Zack O’Malley. Empire State of Mind: How Jay-Z Went from Street Corner to Corner Office. New York, NY: Penguin, 2011. Print.

Hall, Stuart. Cultural Studies 1983: A Theoretical History. Ed. Jennifer Daryl Slack and Lawrence Grossberg. Durham: Duke UP, 2016. Print.

Harrison, Milmon F. Righteous Riches: The Word of Faith Movement in Contemporary African American Religion. New York, NY: Oxford UP, 2005. Print.

Herzog, Lisa. Inventing the Market: Smith, Hegel, and Political Theory. New York, NY: Oxford UP, 2013. Print.

Hess, Mickey. “The Rap Career." That's the Joint!: The Hip-Hop Studies Reader. Ed. Murray Forman and Mark Anthony Neal. New York, NY: Routledge, 2012. 635-654. Print. 
Hopkins, Dwight N. "Slave Theology in the 'Invisible Institution.” African American Religious Thought: An Anthology. Ed. West and Glaude, Jr. Louisville, KY: Westminster John Knox P, 2003. 790-830. Print.

Jay-Z. "Blueprint 2." The Blueprint 2: The Gift \& the Curse, 2002. Roc-A-Fella, CD. "Breathe Easy (Lyrical Exercise)." The Blueprint, 2001. Roc-A-Fella, CD. "Empire State of Mind." The Blueprint 3, 2009. Roc Nation/Atlantic, CD. "Heaven." Magna Carta Holy Grail, 2013. Roc-A-Fella/Roc Nation/UMD, CD. "Justify My Thug." The Blueprint, 2001. Roc-A-Fella, CD.

"Legacy." 4:44, 2017. Roc Nation, MP3.

"No Hook." American Gangster, 2007. Roc-A Fella, CD.

“Rap Game/Crack Game.” In My Lifetime, Vol. 1, 1997. Roc-A-Fella, CD.

"Regrets." Reasonable Doubt. Priority Records, 1996. CD.

"Story of O.J." 4:44, 2017. Roc Nation, MP3.

Johnson, Walter. “On Agency." Journal of Social History. 37.1 (Autumn 2003): 113-124. Print. Soul by Soul: Life Inside the Antebellum Slave Market. Cambridge: Harvard UP, 1999. Print.

R. A. T. Judy "On the Question of Nigga Authenticity." That's the Joint!: The Hip-Hop Studies Reader.

Ed. Murray Forman and Mark Anthony Neal. New York, NY: Routledge, 2004. 105-117. Print.

Lamar, Kendrick. DAMN., 2017. Top Dawg/Aftermath/Interscope, CD.

Good Kid, M.A.A.D City, 2012. Top Dawg/Aftermath/Interscope, CD.

To Pimp a Butterfly, 2015. Top Dawg/Aftermath/Interscope, CD.

untitled unmastered. Top Dawg/Aftermath/Interscope, CD, 2016.

Lee, Shayne. T. D. Jakes: America's New Preacher. New York, NY: New York UP, 2005. Print.

Levine, Lawrence. Black Culture and Black Consciousness: Afro-American Folk Thought from Slavery to Freedom. New York, NY: Oxford UP, 1977. Print.

Lincoln, C. Eric. "The Racial Factor in the Shaping of Religion in America." African American Religious Thought: An Anthology. Ed. West and Glaude, Jr. Louisville, KY: Westminster John Knox P, 2003. 156-186. Print.

MacGilvray, Eric. The Inventions of Market Freedom. New York, NY: Cambridge UP, 2011. Print.

Martin, Lerone A. Preaching on Wax: The Phonograph and the Shaping of Modern African American Religion. New York, NY: New York UP, 2014. Print.

Marx, Karl. "The Eighteenth Brumaire of Louis Bonaparte." The Marx-Engels Reader, Second Edition.

Ed. Robert C. Tucker. New York, NY: Norton, 1978. 594-617. Print.

Matthews, Donald G. Religion in the Old South. Chicago, IL: U of Chicago P, 1977. Print.

McDonald, Roderick A. "Independent Economic Production by Slaves on Antebellum Louisiana

Sugar Plantations." Cultivation and Culture: Labor and the Shaping of Slave Life in the Americas.

Ed. Ira Berlin and Philip D. Morgan. Charlottesville: UP of Virginia, 1993. 275-299. Print.

McGovern, Kyle. "Kanye at NYC Listening Party: 'West Was My Slave Name, Yeezus Is My God Name." Spin. 11 June 2013. Web. 12 March 2018. <https://spin.com/2013/06/kanye-west-yeezusdaft-punk-chief-keef-justin-vernon-tnght-rick-rubin-collaborations $>$.

McLeod, Kembrew. "Authenticity Within Hip-Hop and Other Cultures Threatened With Assimilation."

That's the Joint!: The Hip-Hop Studies Reader. Ed. Murray Forman and Mark Anthony Neal. New York, NY: Routledge, 2012. 165-178. Print.

Miller, Monica R. "God of the New Slaves or Slaves to the Ideas of Religion and God?" The Cultural Impact of Kane West Ed. Julius Bailey. New York, NY: Palgrave MacMillan, 2014. 167-179. Print. . “The Promiscuous Gospel': The religious complexity and theological multiplicity of rap music."

Culture and Religion 101 (2009): 39-61. Print. Religion and Hip Hop. New York, NY: Routledge, 2013. Print.

Miller, Monica R., and Anthony B. Pinn (eds.). The Hip Hop and Religion Reader. New York, NY: Routledge, 2015. Print.

Miller, Monica R., Anthony B. Pinn, and Bernard “Bun B” Freeman, ed. Religion in Hip Hop: Mapping the New Terrain in the US. New York, NY: Bloomsbury, 2015. Print.

Moses, Wilson Jeremiah. Black Messiahs and Uncle Toms: Social and Literary Manipulations of a Religious Myth. University Park, PA: Pennsylvania State UP, 1993. Print. 
Mumford, Debra J. "Rich and Equal in the Eyes of Almighty God!: Creflo Dollar and the Gospel of Racial Reconciliation." Pneuma 33.2 (2011): 218-236. Print.

Nas. "The Cross." God's Son, 2002. Ill Will/Columbia, CD.

Neal, Mark Anthony. "Postindustrial Soul: Black Popular Music at the Crossroads." That's the Joint!: The Hip-Hop Studies Reader. Ed. Murray Forman and Mark Anthony Neal. New York, NY: Routledge, 2004. 363-388. Print.

"Up From hustling: Power, plantations, and the hip-hop Mogul." Socialism and Democracy 18.2 (2004): 157-182. Print.

Negus, Keith. "The Business of Rap: Between the Street and the Executive Suite." That's the Joint!: The Hip-Hop Studies Reader. Ed. Murray Forman and Mark Anthony Neal. New York, NY: Routledge, 2012. 656-671. Print.

Patterson, Orlando. Slavery and Social Death: A Comparative Study. Cambridge: Harvard UP, 1982. Print.

Penningroth, Dylan C. The Claims of Kinfolk: African American Property and Community in the Nineteenth-Century South. Chapel Hill: The U of North Carolina P, 2003. Print.

Pinn, Anthony B. (ed.). Noise and Spirit: The Religious and Spiritual Sensibilities of Rap Music. New York, NY: New York UP, 2003. Print.

Quinn, Eithne. Nuthin' but a "G" Thang: The Culture and Commerce of Gangsta Rap. New York, NY: Columbia UP, 2005. Print.

Raboteau, Albert J. Slave Religion: The "Invisible Institution" in the Antebellum South. New York, NY: Oxford UP, 1978. Print.

Radano, Ronald. "Black Music Labor and the Animated Properties of Slave Sound." Boundary 43 (February 2016): 173-208. Print.

Rael, Patrick. "The Market Revolution and Market Values in Antebellum Black Protest Thought." Cultural Change and the Market Revolution in America, 1789-1860. Ed. Scott C. Martin. New York, NY: Rowman \& Littlefield Publishers, 2005. 13-45. Print.

Rose, Tricia. Black Noise: Rap Music and Black Culture in Contemporary America. Hanover, NH: Wesleyan UP, 1994. Print.

Smith, Christopher Holmes. “I Don't Like to Dream about Getting Paid': Representations of Social Mobility and the Emergence of the Hip-Hop Mogul." Social Text, 21477 (Winter 2003): 69-97. Print.

Sorett, Josef. "Believe me, this pimp game is very religious': Toward a religious history of hip hop." Culture and Religion 101 (2009): 11-22. Print.

Spence, Lester K. Stare in the Darkness: The Limits of Hip-Hop and Black Politics. Minneapolis, MN: U of Minnesota P, 2011. Print.

Taylor, Timothy D. Music and Capitalism: A History of the Present. Chicago, IL: U of Chicago P, 2016. Print.

Tucker-Worgs, Tamelyn N. The Black Megachurch: Theology, Gender, and the Politics of Public Engagement. Waco, Texas: Baylor UP, 2011. Print.

Walker, Juliet E. K. The History of Black Business in America: Capitalism, Race, Entrepreneurship to 1865, Volume I. Chapel Hill: The U of North Carolina P, 2009. Print.

Walton, Jonathan. Watch This!: The Ethics and Aesthetics of Black Televangelism. New York, NY: New York U, 2009. Print.

Watson, Harry L. "Slavery and Development in a Dual Economy: The South and the Market Revolution." The Market Revolution in America: Social, Political, and Religious Expressions, 18001880. Ed. Melvyn Stokes and Stephen Conway. Charlottesville: UP of Virginia, 1996. 43-73. Print. West, Kanye. "Can't Tell Me Nothing." Graduation, 2007. Roc-A-Fella, CD.

The College Dropout, Roc-A-Fella, CD, 2004.

"Diamonds from Sierra Leone." Late Registration, 2005. Roc-A-Fella, CD.

"Diamonds from Sierra Leone (Remix)." Late Registration, 2005. Roc-A-Fella, CD.

Graduation. Roc-A-Fella, CD, 2007.

Late Registration, 2005. Roc-A-Fella, CD.

The Life of Pablo, 2016. GOOD Music/Def Jam Recordings, MP3.

My Beautiful Dark Twisted Fantasy. Roc-A-Fella, CD.

Yeezus. Def Jam, CD, 2013. 